making wildly exaggerated claims about the effectiveness of Allied bombing. Later, Bernal, Patrick Blackett and Zuckerman advised against the bombing of German cities because it was a total waste of manpower and resources.

Bernal and Zuckerman were seconded to Louis Mountbatten's team, which was planning D-day. Bernal's great contribution was to chart the Normandy beaches in detail, identifying every rock, mine and weak spot. His charts turned out to be reliable and the tanks and trucks got ashore.

A strong friendship sprang up between Bernal and Mountbatten, who reported: "Bernal is one of the most engaging personalities I have ever known. Perhaps his most pleasant quality is his generosity. This may be why his great contribution to the war effort has not been properly appreciated." Bernal said of Mountbatten: "He had the habit that great commanders have of acting first and thinking afterwards." Late in the war, Mountbatten became supreme Allied commander in southeast Asia, and Bernal joined him in Ceylon on bomb trials for jungle clearance. $\mathrm{He}$ found himself working alongside John Kendrew and they fell to talking about the structure of proteins - a conversation that had considerable repercussions. Shortly afterwards, Kendrew turned up in Cambridge to work with Perutz on haemoglobin and myoglobin, and Bernal's ideas were later very influential in the founding of the European Molecular Biology Laboratory.

After the war, Bernal resumed his professorial duties at Birkbeck, setting up the Biomolecular Research Laboratory in 1948. As well as groups working on organic crystals and proteins, he had others working on computers, the structure of cements (buildings and building materials were a life-long interest), and the structure of water. Rosalind Franklin later joined him to start work on virus structure, which she continued with Aaron Klug.

Bernal continued his enthusiastic support for the Soviet Union. But he was heavily criticized for his support of Trofim Lysenka, whose ideas were completely incompatible with mainstream genetics. This lapse of judgement on Bernal's part is difficult to understand.

The prospect of nuclear war horrified Bernal, particularly as one of his last acts before leaving government service at the end of the war had been to estimate the cost of destroying the Soviet Union - and of the Soviet Union destroying Britain. Along with Frédéric Joliot-Curie he founded the World Peace Council, which became a vehicle for Soviet propaganda but which might in the end have fulfilled its mission by exercising a restraining influence on Nikita Khrushchev during the Cuban missile crisis.

Bernal wrote profusely on science and society, and many of his revolutionary ideas on science planning are now commonplace. Towards the end of his life he became involved in planning for the Labour party, but his work was cut short by ill health. Repeated strokes left him incapacitated and practically incommunicado - a sad end for a man whose life was based on communication.

This is a very fine (and large) book. Much more than a biography, because of Bernal's involvement in so many sociological issues of his day, it takes the form of a social history of the first half of the twentieth century. Kenneth C.Holmes is at the Max-Planck-Institut für Medizinische Forschung, Heidelberg 69120, Germany.

\title{
In search of Prometheus
}

\section{Bioethics and the New Embryology: Springboards for Debate by Scott F. Gilbert, Anna L. Tyler \& Emily J. Zackin \\ Sinauer: 2005.280 pp. $\$ 14.95$}

\section{James Bradley} questions. What is a person? What ought to be the moral status of human embryos? How should we define 'normal' and human'? Should we genetically engineer future generations of humans? And what about human cloning? A first step towards finding answers to difficult questions is to get the facts. Most people, even well-educated ones, do not have the facts needed to develop informed opinions on these questions. In a university cell-biology dass that I recently lectured, only one of 140 students knew the source of embryonic stem cells; a multidisciplinary group of ten professors did no better.

In a remarkably far-sighted book, The Prometheus Project (Doubleday, 1968), physicist Gerald Feinberg wrote about humanity's need to ponder questions like these. He warned that human genetic engineering, age retardation, chemical and electrical mind modification, and artificial-intelligence technologies would force upon us irreversible decisions that should be the focus of a Prometheus (from the Greek word for 'foresight') project
Modern biotechnology raises some difficult

that would draw on informed thought from all of Earth's peoples.

Decision time is here, but a consensus on who we are and where we are going is nowhere in sight. There has been no Prometheus project. National and state governments, private industry and even cults are going separate ways in research on embryonic stem cells, human cloning, and the creation and use of genetically modified organisms. And the strident voices of scientists, politicians and ethicists are urging us either to embrace the new biotechnologies for their potential benefits or to restrict them for fear of an undesirable future for our species.

Scott Gilbert, a respected developmental biologist and textbook author, has now entered the fray with a calm and rational voice. In Bioethics and the New Embryology, he and his two student co-authors provide information for students, other academics and the public about many of today's most urgent biotechnological issues.

Each of the book's seven sections explains the biology underlying a specific biotechnology and discusses the relevant ethical issues. Topics include early human development and personhood, assisted reproduction, sex selection, human cloning, stem cells, human genetic engineering, defining what is normal, genetic essentialism, and the ethics of using animals in research.

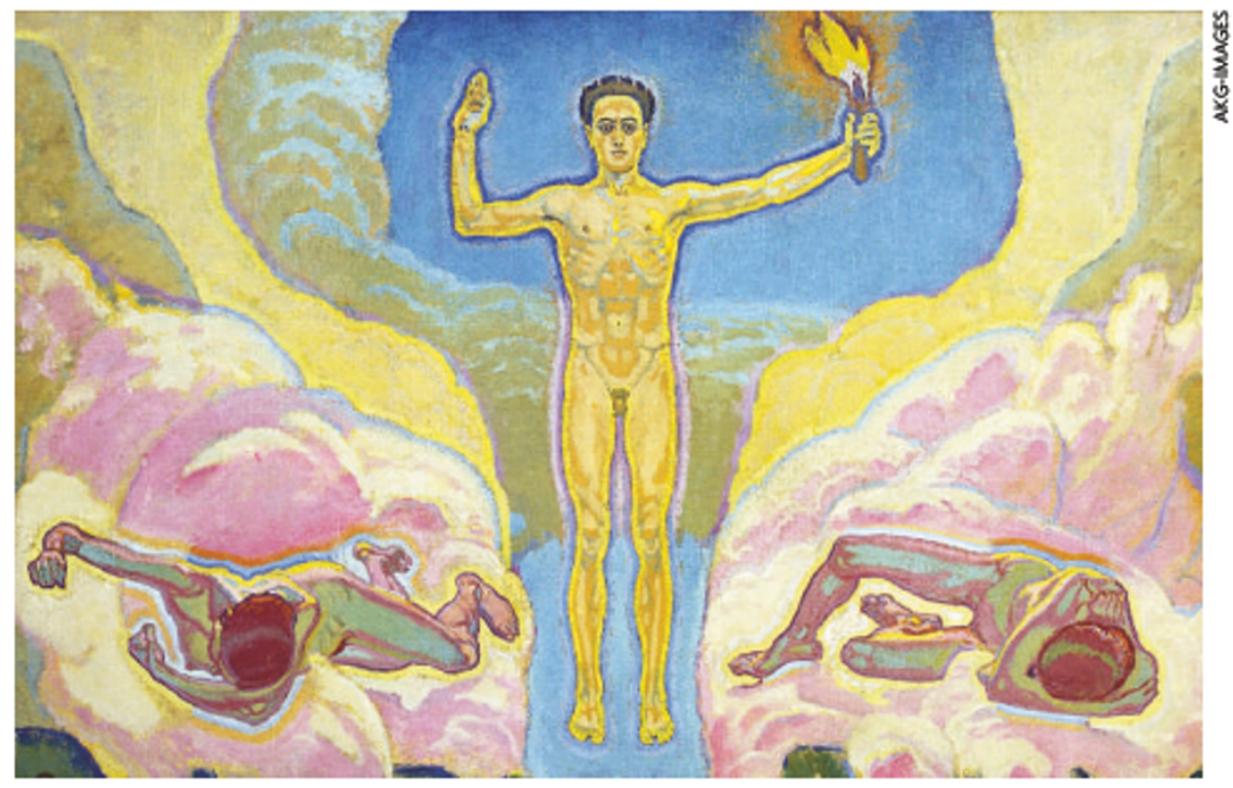

Prometheus unfound? Noproject to explore what we want from biotechnology has been forthcoming. 
Ten short, interspersed essays treat specific biological, ethical and policy issues in greater depth. For example, an essay on contraception tells how a group of pharmacists that was opposed to filling prescriptions for emergency contraception had claimed that 'morning after' pills cause abortions. In fact, the evidence indicates that such pills act by preventing fertilization. This misinformation may result in preventable, unwanted pregnancies. Similarly, false claims by Vatican officials that the HIV virus can pass through intact condoms may jeopardize the lives of women in regions where AIDS is rampant. "The tragic irony," Gilbert writes, "is that being 'pro-life' regarding the creation of zygotes can make one complicit in the deaths of adult men and women." Other essays address preimplantation genetic diagnosis, umbilical-cord stem cells and eugenics. A 200-word glossary and an accompanying $\mathrm{CD}$ with modifiable figures and PowerPoint presentations for each chapter enhance the book's user-friendliness.

The information that Gilbert presents can largely be found in websites and other books, but nowhere else are the biological facts and the bioethical issues gathered and offered up in such a tastefully concise, beautifully illustrated, engaging and easily consumable format. For example, Biotechnology: Demystifying the Concepts by David Bourgaize and coauthors (Benjamin Cummings, 1999) is an excellent introductory survey of molecular genetics, genetic-engineering technologies and associated ethical and policy issues that addresses in 400 pages what Gilbert discusses in just 34. Similarly, 33 of Gilbert's pages very adequately explain the material covered in the 200-page Human Embryonic Stem Cells by Ann A. Kiessling and Scott Anderson (Jones \& Bartlett, 2003). For cross-disciplinary perspectives on cloning, Michael C. Brannigan's Ethical Issues in Human Cloning (Chatham House, 2000) is very good, but so are the corresponding 16 pages in Gilbert's book. To delve deeper into any of the issues he discusses, one can download non-illustrated, book-length reports by the President's Council on Bioethics (www.bioethics.gov).

With its broad-ranging coverage of embryorelated biotechnologies, Gilbert's book makes an excellent text for high-school and university biology students and for bioethics courses. It also superbly meets the need for an accessible, accurate resource for the biotechnological knowledge needed for informed policymaking. Although lay readers may struggle with some of the science, the book is an important contribution to informed dialogue among citizens from a wide range of educational levels, professions and generations - a first step towards a Prometheus project.

James Bradley is in the Department of Biological Sciences, 331 Funchess Hall, Auburn University, Auburn, Alabama 36849, USA. He is currently writing a book for non-biologists called TwentyFirst Century Biotechnologies and Human Values.

\section{Tall tales from the deep}

\section{Singing Whales, Flying Squid and \\ Swimming Cucumbers: The Discovery of \\ Marine Life \\ by Richard Ellis \\ Lyons Press: 2006.288 pp. $\$ 24.95$}

\section{Victor Smetacek}

The news from the sea is depressing these days: depleted fish stocks; turtle, shark and dolphin numbers dwindling at alarming rates; Antarctic blue whales hovering on the brink of extinction; and, looming over all the wanton destruction, are the spectres of pollution, climate change and inexorable acidification. Neptune will be getting very sour. Spreading the bad news is the best one can do these days, hoping that the public at large will realize that the reports warrant red alert.

But not all is gloom and doom. Scientificunderstanding of how oceans and their biota function, and how they interact with the rest of the Earth system to maintain our planet in a habitable state, is growing steadily. But this endeavour of mainstream marine science is more like writing a symphony than painting a big picture. To appreciate the news, one needs to be familiar with the context. Luckily, the sea is also full (or used to be full) of eye-catching animals that appeal to the innate curiosity stimulated by large size and strangeness. Such newsworthy animals continue to be discovered, literally brought to light by the increasing number of searchlights probing the inky vastness. Spreading this type of news is also necessary, as it increases public awareness of the ocean as a fascinating and exciting habitat well worth protecting.

As suggested by its main title, Richard Ellis's book is a collection of short stories on marine animals, selected on the basis of how likely they are to fascinate the reader. The subtitle refers, with few exceptions, to discoveries made by the human eye, and hence on the periphery of mainstream research, which relies on instruments to make its observations. Ellis writes for the public in a breezy, light-hearted style, sometimes struggling to keep up the entertainment level with liberal use of superlatives. He has written many books on good and bad news from the sea, and a glance at some of the titles leaves one wondering how regular readers cope with the repetition. Perhaps the denizens of the deep are indeed so strange that one can write several eye-catching headlines on the same topic.

Ellis is most comfortable writing about big animals and seems out of his depth in the microbial world. He says nothing about the discovery of the archaea, life-forms genetically as distant from bacteria as we are from them. They were first reported from extreme environments but are now being found thriving 